\title{
Gastronomski turizem
}

\author{
Maja Uran Maravić \\ UP Fakulteta za turistične študije - Turistica \\ maja.uran@fts.upr.si \\ Kaja Sajovic \\ RTV Slovenija \\ kaja.sajovic@rtvslo.si
}

\section{Uvod}

Če pogledamo osnovne komponente turističnega sistema, je jasno, da je bila (pre)hrana vedno osnovna komponenta turistične ponudbe in vsakega turističnega proizvoda. Pa vendar je potrebno razlikovati od osnovne potrebe človeka po hrani do tega, kaj je gastronomija, gastronomski turizem, saj je pri slednjem govora o primarnem ali prevladujočem motivu prihoda turista, ki biva vsaj eno noč, na destinacijo.

Kdaj res govorimo o gastronomskem turizmu? Zanimiv je pogled na slovenskem spletnem portalu o gastronomiji www.vivi.si, kjer avtor Uroš Mencinger, dolgoletni kulinarični kritik, doživeto predstavi, kako se berejo gume, in s tem aludira na prihod Michelinovega vodnika v Slovenijo. Pravi, da Michelinove zvezdice predstavljajo tri največje želje vsakega chefa; kuharjev je namreč veliko, le redki med njimi pa postanejo chefi. In še redkejši med chefi dobijo tudi čin. Vsi kuharji si zvezdice želijo zato, ker jih ne morejo vsi dobiti. Vsi go- 


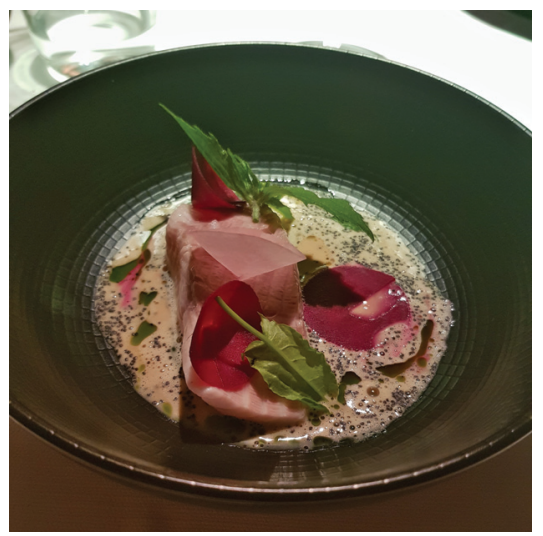

Slika 4.1 Postrv, sirotka, mak na 11-hodnem zimskem degustacijskem meniju 2018 v Hiši Franko (foto Maja Uran Maravić)

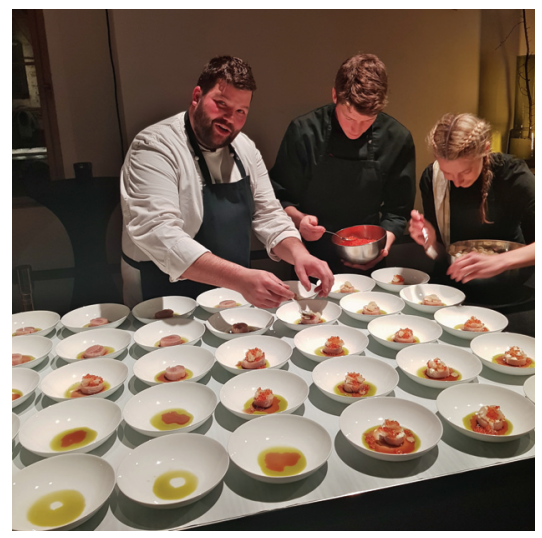

Slika 4.2 Chef Luka Košir, ambasador Slovenije kot Evropske gastronomske destinacije, na European Food Summitu 2019 (foto Maja Uran Maravić)

stje mislijo, da je najboljše le tam, kjer knjiga, ki ima že go let enake, rdeče platnice, daje avtomobilistom le tri napotke: »Za 1 ustavi! Za 2 zavij! Za 3 odpotuj!«

Torej bi lahko povzeli, da gre za prave gastronomske turiste samo v primeru obiskovalcev restavracij s 3 Michelinovimi zvezdicami. Pa temu ni tako. Kot bomo prikazali kasneje v posameznih opredelitvah gastronomskega turizma in proizvodov, številni akademiki danes uporabljajo opredelitev Halla in L. Sharples (2003), ki navajata, da je gastronomski turizem tista vrsta turizma, kjer gre za obisk proizvodov gastronomskega turizma in so ti proizvodi primarni motivacijski dejavnik. Ti proizvodi so na primer: obisk primarnih in sekundarnih proizvajalcev hrane, festivali hrane, restavracije in posebne lokacije za degustacijo hrane in/ali okušanje posebnih regionalnih lastnosti pri pridelave hrane.

Svetovna turistična organizacija (World Tourism Organization, 2012) navaja, da so turisti dandanes izkušenejši, imajo večji razpoložljivi dohodek in več prostega časa za potovanje ter jim turizem omogoča, da se izognejo svoji vsakodnevni rutini, običajnemu okolju ter da se potopijo v svet svobode in novosti. Ravno gastronomija je to področje velike kreativnosti in inovativnosti, hkrati področje odkrivanja novih jedi kot tudi ponovnega odkrivanja starih tradicij in tipičnih jedi posameznih destinacij. 
Z besedami Zuraba Pololikashvilija, generalnega sekretarja Svetovne turistične organizacije (World Tourism Organization, 2019, str. 6): „Gastronomski turizem je sestavni del lokalnega življenja in je prepleten z zgodovino, s kulturo, z gospodarstvom in družbo posamezne destinacije. Predstavlja naravni potencial za obogatitev izkušnje obiskovalcev, vzpostavljanje neposredne povezave z regijami, prebivalci, kulturo in dediščino. Zanimanje za gastronomski turizem v zadnjem času narašča, skupaj s promocijo regionalnih identitet, gospodarskim razvojem in dediščino. Potem ko so destinacije spoznale svoje konkurenčne prednosti, se jih vse več odloča, da bi bile prepoznane kot destinacije za gastronomski turizem."

Temu pritrjuje tudi Gačnik (2014), ki pravi, da gastronomski turizem postaja ena največjih priložnosti in prioriteta Slovenije zaradi povezovalnih ter multiplikativnih učinkov na trajnostni prostorski, družbeni in kulturni razvoj.

Številni avtorji razpravljajo o pomenu in vsebini gastronomskega turizma. To poglavje je namenjeno predstavitvi glavnih opredelitev gastronomskega turizma, predstavitvi trendov, pregledu glavnih znamk/znakov kakovosti na področju gastronomskega turizma, kot so Michelin in Gault Millau, predstavitvi najbolj znanih chefov, pregledu razvoja slovenskega turizma ter predstavitvi krovnega razvojnega dokumenta slovenske gastronomije, ki sta ga sooblikovali tudi avtorici tega poglavja.

\section{Opredelitev gastronomskega turizma}

V literaturi o turizmu, ki se nanaša na hrano, se uporabljajo številni izrazi, in sicer prehrambni in vinski turizem (angl. food and wine tourism), okuševalni turizem (angl. tasting tourism), gurmanski turizem (angl. gourmet tourism), pogosteje še kulinarični turizem (angl. culinary tourism), prehrambni turizem (angl. food tourism) ali gastronomski turizem (angl. gastronomy tourism). Nekateri akademiki trdijo, da so si slednji trije izrazi zelo podobni in se v nekaterih primerih dejansko uporabljajo kot sopomenke. Vendar se ti izrazi običajno pojavljajo v nekoliko drugačnih okoliščinah in pomen vsakega od njih predstavlja različne perspektive (Ellis idr., 2018).

Besedno zvezo kulinarični (gastronomski) turizem je l. 1998 med prvimi opredelila že L. Long, in sicer kot vključenost turista v pokušanje hrane in s tem celostno doživetje kulture obiskanega kraja (Long, 2004). A. Vinerean (2012) pa ga enači s pojmom kulinarični 


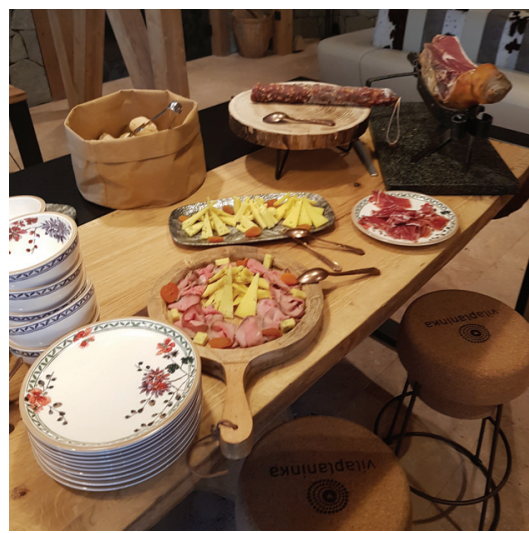

Slika 4.3 Bifejski zajtrk, ponudba lokalnih mesnin v Vili Planinki, 2019 (foto Maja Uran Maravić)

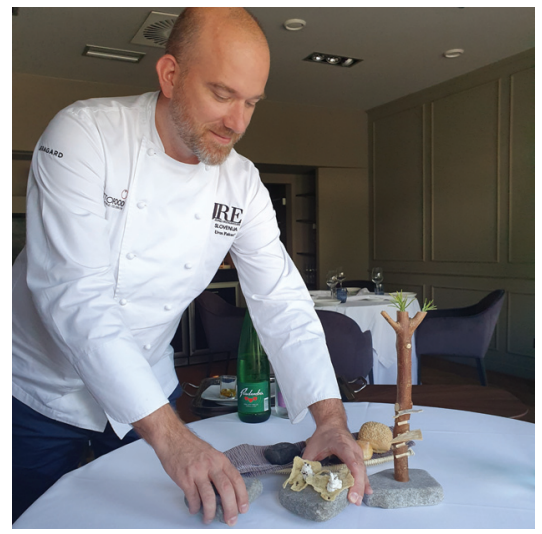

Slika 4.4 Chef Uroš Fakuč, Restavracija in hotel Dam, Nova Gorica, 2019 (foto Maja Uran Maravić)

turizem, degustacijski-okuševalni turizem oz. t.i. prehrambni turizem, kjer je lokalna hrana glavna motivacija za potovanje v določeno državo.

Svetovna turistična organizacija (World Tourism Organization, 2012) poudarja, da je hrana edini del turistične izkušnje, ki spodbuja vseh pet čutil in je zato ena izmed pomembnejših dejavnikov, ki se je turist spominja. Hrana je torej za turiste nepogrešljiv del celostne turistične izkušnje.

Po mnenju A. Ellis idr. (2018) je kulinarični turizem najpopularnejši izraz, ki se ga uporablja za opis te vrste turizma, medtem ko se prehrambni in gastronomski turizem uporabljata manj. Zanimivo tudi opredeljujejo razlike med temi tremi izrazi. Medtem ko naj bi se kulinarični turizem nanašal dejavnosti, povezane s hrano, v smislu kulturne porabe, naj bi se prehrambni turizem nanašal na tista fizična doživetja, ki so motivirana z željo po interakciji z lokalno hrano. Tudi pri gastronomskem turizmu je po mnenju A. Ellis idr. (2018) kultura osrednjega pomena za ta izraz, a je za razliko od kulinaričnega turizma tu bolj osredotočena na gostitelja. Razlagajo, da medtem ko se kulinarični turizem nanaša na kulturno doživetje turistov, gastronomski turizem zadeva mesto hrane v kulturi gostitelja. Drugi, ki sprejemajo uporabo tega izraza, prav tako želijo vključiti in priznati pomen pijač pri definiranju gastronomskega turizma.

Gastronomski turizem se v širšem pomenu nanaša na obiskoval- 
ce, ki potujejo zato, da bi spoznali in poskusili gastronomijo kraja oz. države (World Tourism Organization, 2012). Ožje gledano pa gre za izkustveno doživljanje: obiske proizvajalcev hrane, gastronomske prireditve, obiske restavracij, sejmov, dogodkov, tržnic, predstavitve kuhanja in okušanja kakovostnih pridelkov ter izdelkov in drugih aktivnosti, povezanih s hrano in pijačo. Gre za eksperimentiranje, učenje od drugih kultur in razumevanje značilnosti turističnih ter gastronomskih posebnosti regije (Hall in Sharples, 2003).

S. S. Lebe idr. (2012, str. 139) v Leksikonu turizma izraz gastronomija pojasnjujejo kot:

Gastronomija (angl. Gastronomy, nem. Gastronomie) grško: gaster-želodec; nomos - šega, navada, zakon.

Izraz gastronomija ima v različnih državah več pomenov. Ožje pomeni sicer znanje o pripravljanju jedi, sicer pa pomeni vedo o prehranjevanju (bolje povedano o kulturah prehranjevanja), ki vključuje tako hrano kot pijače. Iz gastronomije izvira tudi izraz gastronom, ki lahko pomeni: (1) strokovnjaka za sestavo jedilnikov in pripravo jedi ali ožje (). sladokusca ali dobrojedca. Po eni strani pomeni gastronomija umetnost usklajevanja jedi in pijač v zanimivo in prijetno celoto, torej združitev kulinarike (umetnost priprave jedi) in enologije (veda o vinu), po drugi jo razumemo kot umetnost kuhanja; v nemškem prostoru pa lahko pomeni beseda gastronomija tudi izraz za ponudnika gastronomskih storitev. Gre torej za poznavanje, izbiro, pripravo in uživanje živil. Gastronomijo pa lahko razumemo tudi kot izraz določenega stila kuhanja (denimo slovenska, francoska ali nemška gastronomija).

S. S. Lebe idr. (2012) tudi pravijo, da je za potrebe aplikacije na področje turizma v slovenskem prostoru najustrezneje uporabljati izraz gastronomija.

Prispevajo pa tudi dobro opredelitev kulinarike (Lebe, 2012, str. 273): „Beseda označuje znanje pripravljanja in ponujanja (dekoriranja) jedi, tudi kuharske sposobnosti. Pojem pokriva predvsem vse $\mathrm{v}$ zvezi s kuhinjo in kuhanjem ter kuharskimi spretnostmi. Uporablja se tudi za širša označevanja (npr. slovenska kulinarika, svečana kulinarika). Izraz je pojmovno ožji od besede gastronomija. Iz pojma izvira tudi izraz za kuharja - kulinarik. Danes namesto pojma kulinarika pogosto uporabljamo besedno zvezo kulinarična kultura.« 
Podobno gastronomijo opredeljuje tudi Galičić v hrvaškem leksikonu gostinstva in turizma (2014, str. 295): „Gastronomija je širši pojem od kulinarike, ker pod tem pojmom razumemo in ta pojem obsega umetnost priprave hrane (ki se pridobi z znanjem in izkušnjami), a tudi poznavanje jedi, izbor pijač in strežbo gostov.«

Ponudba gastronomije za potrebe turizma predstavlja torej zaokroženo, celovito obliko turistične in gastronomske ponudbe kraja, mesta, države ali izbranih ponudnikov. Poleg celovite lahko govorimo tudi o delni ponudbi - slednjo predstavlja posamezni izdelek turističnega in gastronomskega ponudnika v določenem kraju oziroma regiji (Lebe idr., 2006).

Zanimiva je tudi študija B. Okumus idr. (2018), ki kaže izjemno povečan interes preučevanja gastronomskega turizma. Študija preučuje razvoj raziskav gastronomije v štiridesetih letih, med letoma 1976 in 2016, s poudarkom na raziskovalnih temah, metodah raziskovanja, nacionalnih, mednarodnih in interdisciplinarnih ali multidisciplinarnih sodelovanjih ter glavnih raziskovalcih na tem področju. V ta namen je bilo skupno analiziranih 5.333 del in objavljenih dokumentov v zvezi s prehrano v 16 vodilnih revijah s področja gostinstva in turizma od leta 1976 do $2016 \mathrm{z}$ uporabo napredne bibliometrične analize. Po nadaljnji ponovni analizi in odpravi je bilo 462 člankov opredeljenih kot raziskovalnih člankov o hrani in gastronomiji. Ugotovitve raziskave kažejo, da se je popularnost te teme po letu 2000 povečala, a vendar skupno število objavljenih člankov v revijah s področja gostinstva in turizma še vedno zaostaja za drugimi področji. Večina raziskav je bila empirična in je potekala s kvantitativnimi metodami, pomanjkanje pa $v$ naprednih metodoloških pristopih še vedno obstaja.

Kar se tiče obravnavanih raziskovalnih tem, so B. Okumus idr. (2018) ugotovili, da je glede na vsebine vse članke moč razporediti na 8 podpodročij, ki so: varnost hrane, hrana in zdravje, razpoložljivost hrane, kulinarični postopki, angl. operations (npr. kuhanje, postrežba, izbor živil, varnost in higiena), prehranski turizem, hrana in kultura ter hrana in izobraževanje. Članki, ki se osredotočajo na kulinarične postopke, so bili prevladujoči (169 od 462). Tu je vredno ponoviti, da pri tem ne gre za članke in ključne besede, ki se osredotočajo na teme upravljanja, kot so management restavracij, storitveni management, odhajanje zaposlenih, trženje, finance ali drugi podobne koncepte. Večina ključnih besed je vključevala vsaj enega 


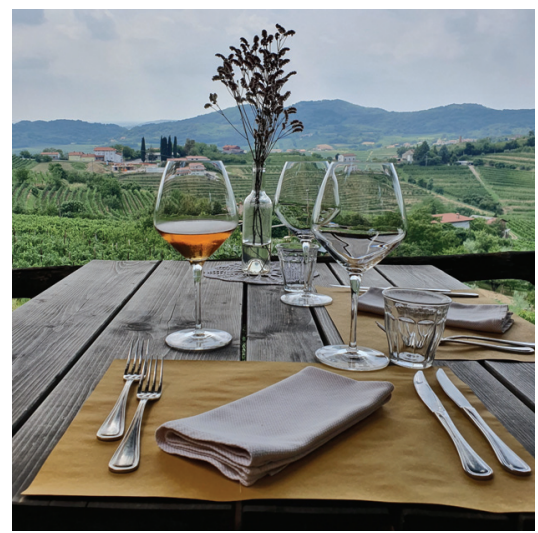

Slika 4.5 Turistična kmetija Klinec, Goriška brda, 2019 (foto Maja Uran Maravić)

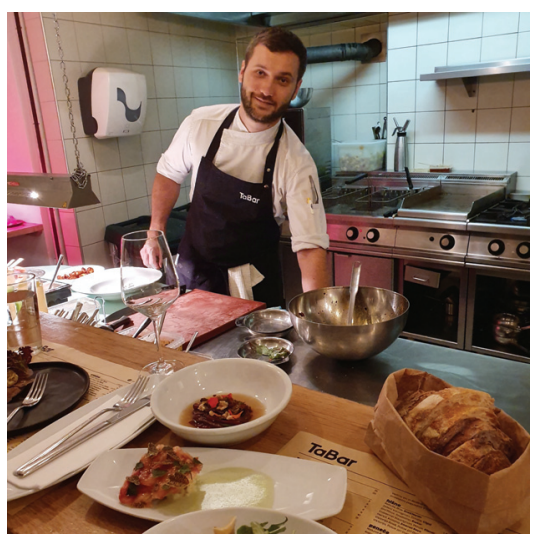

Slika 4.6 Chef Jakob Pintar, restavracija Tabar, mladi chef leta 2020, Gault Millau Slovenija (foto Maja Uran Maravić)

od naslednjih izrazov: hrana, izbira hrane, hrana in socialni mediji, prehranski turizem, lokalna/pristna hrana in restavracije, kuhanje in postrežba za zaposlene, letalska hrana, ulična hrana, otroški meni, chef, kulinarične operacije, oprema, trajnost, oblikovanje menijev, kakovost hrane in sanitarna oskrba. Razen zgoraj naštetih ključnih besed so bile pogosto uporabljene ključne besede o prehranskem turizmu še naslednje: gastronomski/kulinarični turizem; turizem na podeželju; ponudba hrane in izbor destinacije; festivali hrane ter hrana in trajnost.

\section{Trendi v gastronomskem turizmu}

$\mathrm{Z}$ analizo trendov $\mathrm{v}$ gastronomskem turizmu lahko bolje razumemo kontekst razvoja te vrste turizma. Bolje lahko razumemo delovanje turističnega sektorja, pomaga nam razumeti vlogo gastronomije $\mathrm{v}$ današnji družbi, zlasti kot ključni element kulturne dediščine oz. še več, identitete destinacije in posledično glavnega gradnika konkurenčnosti destinacije.

Svetovna turistična organizacija je v krovnem dokumentu za področje gastronomskega turizma zapisala, kaj so glavni trendi in ključi do uspeha v dosedanjem razvoja tega področja (World Tourism Organization, 2012, str. 10-11):

- Rastoči trg te vrste turizma: povpraševanje po gastronomskem 
turizmu strmo narašča; gre za enega najdinamičnejših segmentov na turističnem trgu.

- Poznavanje značilnosti gastronomskih turistov: gre za turiste, ki sodelujejo v novih trendih kulturne potrošnje. So popotniki, ki iščejo avtentične kraje, ki jih spoznavajo skozi hrano. Skrbi jih izvor proizvodov. Vrednost gastronomije prepoznavajo kot sredstvo za druženje, kot prostor za delitev življenja z drugimi, za izmenjavo izkušenj. Takšni turisti nadpovprečno trošijo, so zahtevni, hvaležni ter se izogibajo enotnosti.

- Ozemlje: ozemlje je hrbtenica gastronomske ponudbe. Je element, ki diferencira in je izvor lokalne identitete. Obsega okoljske in krajinske vrednote, zgodovino, kulturo, tradicije, podeželje, morje, lastno kulinariko kraja. V zvezi s tem je pretvorba ozemlja v kulinarično pokrajino eden izmed izzivov turističnih destinacij.

- Proizvod: proizvod je osnova prehranskega turizma. Zato je pomembno opredeliti, katere kulturne in naravne vire bomo pretvorili v turistične proizvode, ki omogočajo identifikacijo tega ozemlja.

- Kulturna dediščina: kultura je skupek vedenj, znanj in običajev, ki oblikujejo družbo in na katerih temelji občutek pripadnosti. Zasnova katere koli ponudbe gastronomskega turizma ne bo izvedljiva, če ne bo upoštevala kulturnih značilnosti ozemlja. Gastronomija turistom omogoča dostop do kulturne dediščine in zgodovine destinacij s pokušino, z doživetji in nakupi. To pomeni, da je mogoče $\mathrm{k}$ njej pristopiti na bolj izkustven in participativen način, ki ni zgolj kontemplativen. Upoštevati moramo tudi nastajanje novih kulturnih vrednot, ki povečujejo bogastvo in kulturno raznolikost države. Tradicija in inovativnost v tem pogledu sobivata na naraven način. Gastronomska tradicija je v procesu nenehne evolucije, izziv strokovnjakov pa je vključiti inovacije, da bi obnovili in prilagodili svojo ponudbo potrebam novega kulturnega potrošnika.

- Trajnost: gastronomski turizem lahko reši kulturne in okoljske probleme na način, ki je združljiv s čisto ekonomskimi argumenti. Nedavna zgodovina razvoja svetovnega turizma je polna nominalno trajnostnih modelov in očitno nevzdržnih ukrepov. Ideja ni ustvariti nov neselektivni pritisk na kulinarično dedi- 
ščino, temveč racionalno spodbujati njeno trajnost. Ne gre za turistično valorizacijo gastronomije $\mathrm{z}$ ustvarjanjem novih ponudb ali povečanjem obstoječih. Ne gre toliko za ustvarjanje, da bi pritegnili, temveč za privabljanje obiskovalcev, da sodelujejo v kulturni resničnosti destinacije, ki je dobro razložena in interpretirana, s pomočjo kulinarike, lokalnih izdelkov in vseh storitev ter dejavnosti, ki jih obkrožajo.

- Kakovost: destinacije, ki želijo promovirati gastronomski turizem, morajo delovati na različnih ravneh na področju kakovosti - zaščita in prepoznavanje lokalnih proizvodov, razvoj konkurenčne ponudbe, strokovnost človeških virov v celotni vrednostni verigi gastronomskega turizma s pomočjo usposabljanja in prekvalifikacije, zaščita in sprejem potrošnikov, da bi povečali njihovo zadovoljstvo.

- Komunikacija: destinacije morajo sporočati verodostojno in avtentično zgodbo o svoji ponudbi gastronomskega turizma. Potovalna izkušnja se je spremenila in ni omejena na dneve dejanskega potovanja, temveč se začne že prej, s pripravo (turist postane navdahnjen, zbira informacije, primerja, kupi), izkušnja pa se konča, ko potnik oceni in deli svoje izkušnje prek družbenih omrežij. Ključne vloge $\mathrm{v}$ tem procesu izgradnje imidža destinacije igrajo: veliki chefi, ki so v segmentu vrhunske kulinarike zagnali revolucijo in revitalizirali to komponento turizma, mediji (predvsem televizija), turistični vodniki, gastronomski blogi in družbena omrežja. Destinacije morajo biti prisotne in aktivne v vseh kanalih in vseh delih tega postopka.

- Sodelovanje: deležniki, ki delujejo na destinacijah (proizvajalci, poznavalci, kmeti, ribiči, chefi, gostinci, javna uprava, hotelirji itd.) morajo biti vključeni v oblikovanje ponudbe gastronomskega turizma.

Poleg teh trendov so zanimivi tudi komercialnejši trendi, ki jih vsako leto predstavi svetovalno podjetje Edelman, ki je med 19 glavnimi gastronomskimi trendi za leto 2019 med drugim navedlo tudi diete na podlagi posameznikovega $\mathrm{DNK}$, superpraške, alternativna masla in olja, neuporabo plastike, ženske vodje, nenavadne kombinacije okusov, ponovno večjo popularnost čaja, "pametno « pridelavo hrane, ponovno uporabo hrane, nove oblike restavracij (virtualne ali restavracije duhovi), vodo kot glavno valuto, avtonomno dostavo hra- 
ne (z droni), lokalne nakupe hrane in davek na meso (https:/ /www .edelman.com).

\section{Znamke kakovosti na področju gastronomije}

Vedno znova se na različnih področjih delovanja pojavi potreba po identifikaciji najboljših ponudnikov. Isto velja tudi na področju gastronomije, kjer so ob najboljših chefih najbolj poznane znamke ravno različni sistemi, ki so razglasili najboljše chefe.

Na področju gastronomije poznamo različne ocenjevalne postopke in sisteme ocenjevanja restavracij, vodnike po restavracijah, znake kakovosti restavracij in drugo, ki so predstavljeni v tujih in domačih virih (Sibila idr., 2006; Uran Maravić, 2014; 2017; Slovenska turistična organizacija, 2016). Restavracije ocenjujejo:

- strokovnjaki (kot npr. Michelin, Gault Millau in AAA Diamonds),

- gosti na spletu (npr. Yelp, Zagat in Trip Advisor),

- novinarji in kulinarični kritiki,

- akademiki s pomočjo različnih akademskih modelov in inštrumentov (SERVQUAL, DINESERV) ...

V slednjih posamezniki ne ocenjujejo le končnega proizvoda, marveč tudi proces izvajanja storitev (Marković idr., 2010).

V znanstveni monografiji Ocenjevanje kakovosti v gostinstvu (Uran Maravić, 2017) so podobno predstavljeni nekateri sistemi:

- v tujini: Michelin, Gault Millau, The World's 50 Best Restaurants (50 najboljših restavracij sveta);

- v Sloveniji:Znak kakovosti ljubljanskega turizma, The Slovenian Restaurant Award.

\section{Najbolj znani chefi}

Medtem ko je jasno, da je strokovno gledano najvplivnejši vodnik Michelin in da je najprestižnejša lestvica 50 Best, je težje najti konsenz, kateri chef je najboljši oz. najbolj znan. Lahko bi presojali po tem, kdo ima največ Michelinovih zvezdic ali kdo je največkrat zmagal na 50 Best ali kdo ima najbolj gledano televizijsko oddajo ali koga so chefi uvrstili na lestvico najboljših ipd. Verjetno nikoli ne bi prišli do usklajenega mnenja o tem, kakor je tudi nemogoče opredeliti, katera je najboljša glasba ali kateri je najboljši film. 
Kakor koli že, vseeno je potrebno omeniti nekaj chefov, ki so ali še zaznamujejo vrh gastronomije. Ob tem poudarimo, da bomo zagotovo kakšnega zelo pomembnega tudi izpustili.

Joël Robuchon je bil francoski chef, ki je imel rekord med vsemi chefi, saj je osvojil največ Michelinov zvezdic v enem letu, in sicer 32 zvezdic naenkrat. Upokojil se je pri 5o. letih, se posvetil odpiranju novih restavracij po svetu pod njegovim imenom in tako zbral tako impresivno število zvezdic. Bil je mentor številnim znanim chefom, med drugim tudi Gordonu Ramsayu, britanskemu chefu, ki je v svoji karieri v enem letu osvojil največ 16 zvezdic, a je kasneje zaslovel predvsem kot televizijska kulinarična zvezda v ZDA in po svetu, in sicer z oddajami, kot so ameriška verzija Masterchefa, Hell's Kitchen, Gordon's Great Escape, Ramsay's Best Restaurants, Hell Hotel in številne druge. Drugi z največ zvezdicami (18) je Alain Ducasse, prav tako francoski chef $\mathrm{z}$ restavracijami na najprestižnejših mestih v Parizu, Londonu, Monte Carlu itd.

Gordon Ramsay ni edina britanska mednarodna gastronomska zvezda. To sta zagotovo tudi Heston Blumental in Jamie Oliver. Prvi je bil s svojo eksperimentalno kuhinjo s The Fat Duck tudi prvi na lestvici 50 Best v letu 2005 (drugi na lestvici v letih 2004, 2006, 2007, 2008, 2009), drugi pa je s svojim aktivizmom želel vrhunsko kuhinjo poenostaviti in jo prilagoditi vsakodnevni pripravi hrane za laike. Kasneje se je tudi zelo angažiral za izboljšanje prehrane v šolah in za vključevanje brezposelnih v delo v gostinstvo, zaradi česa je odprl verigo restavracij Fifteen in zaradi nje skoraj tudi finančno propadel. Oba sta posnela številne televizijske oddaje.

Na drugi strani pa so chefi, ki so mednarodno zasloveli z uvrstitvijo na 50 Best oziroma na prvo mesto te lestvice. V zadnjem času zagotovo najbolj izpostavljen je Rene Redzepi, chef in lastnik kulthe danske restavracije Noma. K. Sajovic (2019) pravi, da se zdi, da v kulinaričnem svetu obstajata dva tabora - tisti, ki se jim Noma zdi preveč eksperimentalna, in tisti, ki prisegajo, da je tudi po 15 letih to najboljša restavracija sveta, brez konkurence. Ko se je odprla, je orala ledino, ne le v Köbenhavnu, ki je bil takrat daleč stran od kulinarične destinacije, kar je danes, ampak v celotni Skandinaviji. Regija takrat pač ni bila znana po dobri hrani. Restavracije, vredne obiska, bi lahko prešteli na prste ene roke, gastronomske tradicije ni bilo - in to čeprav nordijske dežele ponujajo toliko izjemnih surovin, od morskega življa do divjadi. Redzepi, sin albanskega očeta iz Makedonije 


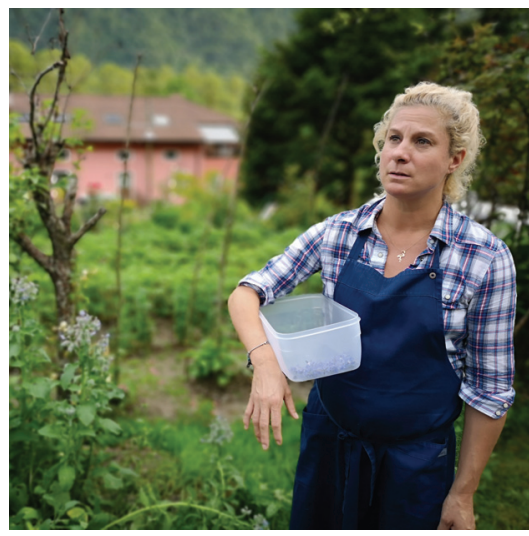

Slika 4.7 Ana Roš (foto Kaja Sajovic)

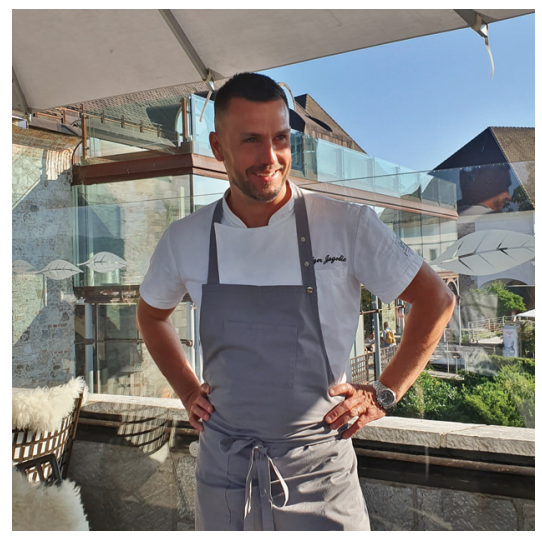

Slika 4.8 Igor Jagodic, chef leta 2019 po izboru Gault Millau Slovenija (foto Maja Uran Maravič)

in danske mame, je bil star komaj 26 let, ko je leta 2003 skupaj s kolegom Clausom Meyerjem, soustanoviteljem Nome, po vzoru Baskov spisal manifest nove nordijske kulinarike, $v$ katerem sta postavila dokaj preproste cilje, ki pa so se izkazali za revolucionarne. Danes se ti cilji zdijo sami po sebi umevni. Takrat, v tistem delu sveta, so bili daleč od tega. Odražanje letnih časov na krožnikih, povezovanje in sodelovanje z lokalnimi pridelovalci, uporaba lokalnih živil in medsebojno deljenje znanja, ker so se Redzepi, Meyer in mladi kolegi, ki sta jih pritegnila, dobro zavedali, da potrebuješ več kot eno restavracijo, da lahko zraseš v kulinarično destinacijo. Leto dni pozneje se je odprla Noma, v kateri je Redzepi natančno sledil vsem tem aksiomom, se poglobil v nordijske dežele in iz nekaterih relativno nepretresljivih surovin, kot so gomoljnice ali lišaji, postavil najboljšo restavracijo sveta.

V času, ko sta na vrhu lestvice 50 najboljših restavracij sveta še kraljevala molekularni El Bulli (najboljša restavracija v letih 2006-2009) in klasika French Laundryja (najboljša v letih 2003 in 2004), se je restavracijski sceni od nikoder "zgodil« Redzepi. Noma je bila na vrhu seznama štirikrat (2010, 2011, 2012 in 2014), a bolj kot njene uvrstitve je bistveno postavljanje skandinavske kuhinje na svetovni zemljevid gastronomskih destinacij. In zanimivo, restavracija ima zgolj $2 \mathrm{Mi}-$ chelinovi zvezdici. V letu 2019 je mesto najboljšega po lestvici 50 Best prevzel Mauro Colagreco z restavracijo Mirazur. 
Poleg Francozov, Britancev in Dancev zagotovo ne smemo izpustiti Špancev in Baskov, kot so Ferran Adria (el Bulli je bil 5-krat najboljši na lestvici 50 Best), bratje Roca (restavracija El Celler de Can Roca je zmagala dvakrat), Juan Maria Arzak, Andoni Luis Aduriz, uvrščen na 7. mesto na lestvici 50 Best $\mathrm{z}$ restavracijo Mugaritz in je bil tudi chef leta 2008 in 2012, Italijanov, kjer je zadnje čase na lestvici 50 Best najbolje uvrščen Massimo Bottura (zmagal dvakrat), Južnoameričanov Virgilia Martineza in Alexa Atalaja ter azijskih chefov, kot je Gaggan Anand, katerega restavracija je bila na lestvici 50 Best štiri leta zapored (2014-2018) proglašena za najboljšo v Aziji, in številni drugi. Kot že rečeno, težko je narediti izbor najboljših, saj je tistih, ki so na takšen ali drugačen način zaznamovali svetovno gastronomijo, ogromno, žal je med njimi malo žensk. A med tistimi, ki so jo, je prav gotovo tudi Slovenka Ana Roš, ki je bila tudi uvrščena med Netflixov izbor najzanimivejših 12 chefov oz. v drugo sezono te popularne oddaje.

\section{Razvoj slovenske gastronomije skozi čas}

Gastronomija (tudi kulinarika oz. prehranska kultura) na območju današnje Slovenije se je skozi zgodovino razvijala na stičišču Alp, Mediterana, Panonske nižine in Balkana. Prav to je ustvarilo pestro prehransko kulturo, kjer ne moremo govoriti le o prevzemanju okusov od sosedov in ljudstev, živečih na našem ozemlju, ampak tudi o stalnem prilagajanju in inovativnem ustvarjanju novih okusov.

V procesih izoblikovanja slovenske gastronomske prepoznavnosti so se prepletala različna družbena okolja, ki so pomembno sooblikovala kuharsko znanje. Staroselske kulture so bile zelo povezane s predelavo mleka v mlečne izdelke, vendar se skoraj niso ohranile. Prehrana večinskega kmečkega prebivalstva je bila skromna, povezana z žitno kulturo, s stročnicami in z okopavinami. Prazničnost so predstavljali le izdelki ob zakolu prašiča.

Skozi zgodovino so novosti, kot so npr. uvajanje triletnega kolobarjenja s praho, izdelki z ajdo, uživanje svinjskega mesa od protestantizma dalje in jedi iz podonavske kuhinje, spreminjale prehransko kulturo. Ta je doživela prelomnico v času razsvetljenstva, ko je l. 1799 Valentin Vodnik izdal prvo kuharsko knjigo v slovenščini z naslovom Kuharske bukve (Vodnik, 1799) Z njo smo slovenski jezik in s tem našo gastronomijo postavili ob bok velikim svetovnim jezikom ob koncu 18. stoletja. Leta 1868 pa je Magdalena Pleiweis napisala 
prvo slovensko kuharico (Pleiweis, 1868), ki je s poznejšimi dopolnitvami drugih avtoric še danes, poleg Slovenske kuharice Felicite Kalinšek (2020), pogosto ponatisnjena.

Leta 1937 so v okviru Združenja gostilničarjev Slovenije ustanovili prvo poklicno gostinsko šolo v Ljubljani, ki od leta 1945 deluje kot prva srednja šola za turizem in gostinstvo.

Po koncu druge svetovne vojne se je vpliv kulinarike z Balkana povečal z migracijami tamkajšnjih prebivalcev v Slovenijo. Na jedilnikih se pojavijo mediteranske pice in balkanski burek, v 6o. letih prejšnjega stoletja tudi žar s čevapčiči in ražnjiči. Od 8o. let 20. stoletja naprej se razvijajo nove restavracije in butične vinske kleti. Narašča gastronomska ozaveščenost in v 9o. letih se uveljavi gibanje Slow Food, ki je na to območje prišlo iz Italije. Vedno več je literature o kulinaričnih in gastronomskih značilnostih, organizirana so vinska združenja in neformalne skupnosti, ki skrbijo za dvig vinske in pivske kulture ter povezanost slovenskih vin s hrano.

Leta 2005 se je Slovenija vključila v najstarejšo svetovno gastronomsko verigo Chaîne des Rôtisseurs. Leto kasneje je bila napisana Strategija razvoja gastronomije Slovenije, ki poleg nacionalnega gastronomskega bogastva in sodobnih oblik predstavlja 24 gastronomskih območij oz. 365 slovenskih prepoznavnih jedi in pijač. Leta 2007 se je Slovenija pridružila zvezi JRE (Jeunes Restaurateurs d'Europe), ki združuje več sto mladih kuharjev po vsej Evropi in Avstraliji. Leta 2018 je pri nas izšel mednarodni gastronomski vodnik Gault \& Millau, oktobra istega leta pa je bil Sloveniji podeljen tudi uradni naziv Evropska gastronomska regija 2021 (angl. European Region of Gastronomy) (Slovenska turistična organizacija, 2018).

Slovenija se ponaša s kuharskimi mojstri, uveljavljenimi tudi v tujini:

- Andrej Kuhar z Michelinovo zvezdico v Nemčiji,

- Joško Sirk z zvezdico za restavracijo Pri Lovcu v Subidi pri italijanskem Krminu,

- Janez Bratovž z restavracijo Jв v Ljubljani z uvrstitvijo na San Pelegrinovo lestvico 100 najboljših restavracij sveta (2010),

- Ana Roš z nazivom najboljšega ženskega chefa sveta (2017) in s Hišo Franko edina iz Slovenije na seznamu The World's 50 Best Restaurants; je tudi članica številnih mednarodnih združenj in gostja na največjih mednarodnih kulinaričnih kongresih, 
- Tomaž Kavčič, Jure Tomič (1. 2016 svetovni prvak v pripravi testenin), Luka Košir, Bine Volčič, Jorg Zupan, Jakob Pintar idr.

Na področju kulinarike izstopajo slovenski vinarji, ki so v tujini prepoznavnejši in dejavnejši od kuharjev. Posamezne vinske kleti, kot sta Movia in Kabaj, sta na seznamu 100 najboljših kleti po izboru revije Wine Spectator. Prepoznavni so tudi Radikon, Gravner, Princic, Terpin, Marjan Simčič, Klinec, Aci Urbajs, Burja ...

Veliko uspehov na tujih trgih doživljajo briške kleti, kjer posamezniki v tujino izvozijo tudi do $90 \%$ steklenic vina. Poseben status imajo slovenska sonaravno in biodinamično pridelana vina, še posebej t. i. oranžna oz. jantarna vina, o katerih je v knjigi Amber Revolution pisal tudi publicist Simon J. Woolf (2018).

Čeprav so gostilne in turistične kmetije eden od prepoznavnih znakov Slovenije, so premalo navezane na lokalno okolje. Med gostilnami z bogato družinsko tradicijo jih le nekaj ohranja vrhunsko kakovost. Prav tako je pri ponudnikih na turističnih kmetijah, kjer pogosto ne strežejo hišnih oziroma lokalnih izdelkov.

Kljub uspehom posameznikov, izpostavljanju Slovenije kot nove gastronomske destinacije in razvoju lokalnih projektov pa obiskovalci Slovenije na prvem mestu ne izpostavljajo gastronomskih doživetij. Le-ta so postala prepoznavna točka turizma v skandinavskih in južnoameriških državah in s tem pritegnila množico novih segmentov turistov. Ti pri kulinaričnih obiskih ne iščejo (le) kakovostnih restavracij, nagrajenih s priznanji (npr. z Michelinovimi zvezdicami), ampak jih zanimajo predvsem lokalno okolje, povezava $\mathrm{z}$ naravo, $\mathrm{s}$ podeželjem, mali, butični proizvajalci, vinogradniki, ribiči, nabiralci, gobarji, sirarji ... Sem spadajo (tudi) t.i. gastronomski turisti (t.i. foodieji), ki so pripravljeni zapraviti največ, veljajo za dobre goste, povečini jih zanimajo tudi kultura, zgodovina, tradicija in povezanost $\mathrm{z}$ naravo.

Veliko državam je uspelo zgraditi svojo podobo v povezavi z okoljem in naravno danostjo, s promoviranjem t.i. kilometra nič, z gradnjo tradicije. Slovenskih restavracijam in gostilnam manjkata nacionalna identiteta in samozavest, kljub temu da imamo bogato in raznovrstno gastronomsko tradicijo. Hkrati je nujno potrebno povezovanje z okolico, z okoliškimi dobavitelji, malimi kmeti in vinarji ter izpostavljanje neokrnjene narave (Slovenska turistična organizacija, 2018). 
Vrhunske restavracije v mestih so s široko (tudi tujo) vinsko ponudbo nujno potrebne za določeno vrsto gastronomskih turistov. Niso pa to nujno turisti, ki jih zanima Slovenija kot zelena, butična destinacija, ki je povezana z okoljem. Bolj ekološko usmerjeni gastronomski turisti so pripravljeni potrošiti precej več denarja od povprečnega turista. Le-ta je za hrano in pijačo pred leti namenil tretjino dnevnega proračuna (World Tourism Organization, 2012). Zadnji podatki za Slovenijo kažejo, da povprečni turist pri nas v lokalih porabi le še polovico, tj. 15,5 odstotka dnevnega proračuna (Slovenska turistična organizacija, 2016).

\section{Akcijski načrt razvoja in trženja gastronomskega turizma}

Avgusta 2018 je skupina strokovnjakov UP FTš Turistice pridobila projekt Slovenske turistične organizacije (sto) za oblikovanje strateškega dokumenta Akcijski načrt razvoja in trženja gastronomskega turizma $v$ Sloveniji 2019-2023 (Slovenska turistična organizacija, 2018), ki bi opredeljeval smernice in ukrepe razvoja in trženja gastronomskega turizma v Sloveniji. Zavezo oblikovanja takšnega dokumenta je sтo sprejela ob kandidaturi za Evropsko gastronomsko regijo. Šlo je za prvi strateški dokument na področju gastronomije po strategiji iz leta 2006.

Priprava dokumenta je bila sestavljena iz več faz, z namenom temeljito preučiti, kako dosedanji in bodoči razvoj gastronomije vidijo ključni deležniki, kar smo ugotavljali s pomočjo intervjujev in delavnic, da bi pridobili glavne usmeritve. Sestavlja ga več poglavij:

- uvodni povzetek - povzetek ključnih misli,

- temeljna izhodišča - opredelitev gastronomskega turizma, pregled razvoja slovenske gastronomije in trga gastronomskega turizma ter swoт-matrika,

- glavna strateška področja - opredelitev glavnih področij delovanja in ukrepov,

- organizacijski okvir - opredelitev, na kakšen način in kdo bo odgovoren za uresničevanje zastavljenih ukrepov in ciljev,

- pregled strateških prioritet - kjer so navedeni vsi ukrepi in nosilci,

- evalvacija - način uspešnosti izvajanja ukrepov in doseganja ciljev,

- metodologija dela - kako je bil dokument oblikovan. 
Naročnik sтo je že v razpisu določil vizijo razvoja. Vizija je, da Slovenija postane prepoznavna gastronomska destinacija $\mathrm{z}$ visokokakovostno, inovativno, avtentično ponudbo hrane in vina, ki jo ustvarjajo številni butični ponudniki z veliko bero najprestižnejših nagrad in tradicionalne gostilne, ki s svojo ponudbo temeljijo na lokalni trajnostni pridelavi in srčnosti. Gastronomija je motiv prihoda vse leto.

Dokument je nastal z namenom doseganja treh ključnih ciljev razvoja in trženja gastronomije - ustvarjanja višje dodane vrednosti, zagotavljanja trajnosti in predvsem povečanja mednarodne prepoznavnosti. Za prepoznavnost Slovenije kot gastronomske destinacije in ne kot destinacije, ki ponuja tudi gastronomijo, pa so ključni angažiranost v mednarodnih ocenjevanjih, prisotnost slovenskih predstavnikov na mednarodnih kulinaričnih kongresih in zagotavljanje visoke kulinarične ter vinske ponudbe, kar pa gre z roko v roki s Slovenijo kot zeleno, trajnostno in nasploh močno z neokrnjeno naravo povezano državo.

Sodelujoči v procesu nastajanja dokumenta so si bili skoraj enotni, da je zanje bistvena podpora Sloveniji pri vključevanju v mednarodna ocenjevanja (Michelin, Gault \& Millau) in podpora chefom za uvrstitev na lestvico The World's 50 Best Restaurants. Na slednji je za zdaj samo Hiša Franko, ki pa že izvaja v tujini običajno prakso fokusiranih študijskih tur za novinarje (predvsem tiste, za katere se sluti, da so člani akademije The World's 50 Best Restaurants). Zato je ta študijska potovanja, ki so se izkazala za učinkovito orodje za promocijo destinacije, nujno treba razširiti na vso državo in vanje vključiti širši krog izbranih posameznikov.

Vrha, ki bi se lahko ob Hiši Franko uvrščal na seznam The World's 50 Best Restaurants in bi posledično vplival na oblikovanje percepcije gastronomskih turistov, da je Slovenija gastronomsko razvita destinacija, sicer ni mogoče zgraditi brez trdne baze ponudnikov, ki bi jo morale sestavljati gostilne s kakovostno lokalno hrano in z lokalnimi surovinami ter izbrano karto vrhunskih lokalnih vin. Prav pri gostilnah in turističnih kmetijah je pri nas največ potenciala - in največ pomanjkljivih točk. Potrebni sta izobraževanje in ozaveščanje ponudnikov, da se obrnejo v strogo lokalno, slovensko, tudi doma pridelano hrano, če gre za turistično kmetijo, hkrati pa pokažejo dovolj domiselnosti in smisla za sodobne trende ter tehnike.

Dejstvo je, da se je v zadnjih letih gastronomski turizem zelo razvil 
in postal eden pomembnejših elementov kakovosti turistovega doživetja. Gastronomija je izredno pomembna za spodbujanje lokalnega, regionalnega in nacionalnega ekonomskega razvoja, gastronomski turisti pa so običajno dobri gostje, $\mathrm{z}$ več proračuna za trošenje na dopustu, bolj okoljsko ozaveščeni in z več interesa za spoznavanje tujih kultur.

Kljub uspehom posameznikov, z Ano Roš na čelu, in vse večjemu izpostavljanju Slovenije kot nove gastronomske destinacije ter razvoju lokalnih prehranskih znamk pa obiskovalci Slovenije kot enega glavnih motivov za obisk še vedno ne izpostavljajo gastronomskih doživetij. Morda tudi zato povprečni turist pri nas v lokalih porabi le pičlih 15,5 odstotka dnevnega proračuna.

Sloveniji najkonkurenčnejše kulinarične destinacije so sosede Hrvaška (zlasti Istra, ki gradi na vinu in posameznih produktih, kot so tartufi), Avstrija z dobro prakso navezovanja narave in malih proizvajalcev na celostno gastronomsko identiteto in podobo države, Madžarska kot primer majhne države z relativno zahtevno kulinariko, ki se ji je uspelo povzpeti do statusa enega vodilnih $\mathrm{v}$ tem koncu Evrope, tudi z vse več Michelinovimi zvezdicami, in Italija, ki ima vzorčen primer dobro postavljene gastronomske piramide $\mathrm{z}$ izjemnimi trattoriami.

Sloveniji ter slovenskim restavracijam in gostilnam prav to manjka - večja nacionalna prehranska identiteta in samozavest. Med prednostmi Slovenije lahko poudarjamo raznolikost na majhnem prostoru, vrhunska in izvirna vina, bogastvo neokrnjene narave, ohranjeno prehransko dediščino, butičnost in zadnje uspehe Ane Roš na mednarodnem prizorišču. Po drugi strani lahko med slabostmi izpostavimo pomanjkanje kadra in nizko usposobljenost strežbe, ki se približujeta kritičnim razsežnostim, slabo povezanost ponudnikov, nizko mednarodno prepoznavnost in nizko kakovost ponudbe.

Raziskave kažejo, da so za nas najpomembnejši trgi Italija, Avstrija, Nemčija pa tudi Francija, Velika Britanija in nekatere skandinavske države. Za določen segment gastronomskih turistov so zagotovo nujno potrebne elitne mestne restavracije s široko (tudi tujo) vinsko ponudbo, niso pa ravno nujno to tisti turisti, ki jih resnično zanima doživeti Slovenijo kot zeleno, butično destinacijo, trdno povezano z okoljem, kar pa bi moralo biti naše primarno orodje trženja destinacije. Skratka, potrebno je privabiti predane gastronomske turiste, ki zapravijo veliko in ki jih zanima tudi spoznavanje tradicij ter 
kulture destinacije, za to pa moramo ponuditi čim več posebnih doživetij in čim več tistega, kar dela Slovenijo in slovensko gastronomsko ponudbo drugačno od konkurenčnih držav.

Krovna zgodba Slovenije kot gastronomske destinacije izhaja iz glavnih prednosti, kaj ima destinacija - katere so značilnosti ponudbe ( $t$ j. naše prednosti). Slovenska gastronomska ponudba je relativno enakomerno razpršena med vrhunskimi restavracijami, kakovostnimi restavracijami in gostilnami, z dodatkom vinskih kleti, turističnih kmetij, gorskih koč in doživetij v naravi, običajno vezanih na glampinge ali posebno/dodatno ponudbo v nastanitvenih obratih. Ena od naših ključnih prednosti je neokrnjenost narave in njena raznolikost na majhnem prostoru, ki omogoča hitro dostopnost do izjemnega naravnega bogastva (velika količina surovin). Za razvoj gastronomije in vrhunskih gastronomskih doživetij so potrebna tudi vrhunska vina in Slovenija ima mednarodno prepoznavne vinarje in vina (domovina rebule, lokalna in regionalna vina, nišna naravna vina). Slovenija zelo skrbi za varnost hrane, zato je tudi prepoznana kot država $\mathrm{z}$ visoki higienskimi in sanitarnimi standardi. Eden največjih indikatorjev čistosti in ohranjenosti naravnega okolja je prisotnost čebele ter bogata tradicija čebelarstva v Sloveniji (ima eno največjih števil čebelarjev na prebivalca v EU - en čebelar na 200 prebivalcev). Odnos do narave se kaže tudi v tradiciji in odnosu lokalnih prebivalcev do pridelave lastne hrane (vrtičkarstvo) in uživanju v bivanju v naravi (nabiralništvo - gobe, zelišča, jagodičevje). Slovenija je v Evropski uniji zaščitila nekatere kmetijske pridelke in živila z zaščiteno označbo porekla (sir tolminc, bovški sir, nanoški sir in mohant, piranska sol s solnim cvetom, kočevski gozdni med in kraški med, istrski pršut in ekstra deviško olje slovenske Istre), zaščiteno geografsko označbo (kranjska klobasa, kraški pršut, kraški zašink, kraška panceta, prekmurska šunka, zgornjesavinjski želodec, šebreljski želodec, prleška tünka, štajersko prekmursko bučno olje, ptujski lük, jajca izpod Kamniških planin, štajerski hmelj in slovenski med) in zajamčeno tradicionalno posebnostjo (belokranjska pogača, prekmurska gibanica, idrijski žlikrofi in slovenska potica (v postopku)). Na koncu, a zagotovo ne najmanj pomembni, so glavna prednost slovenske gastronomije - ljudje, ki s svojim znanjem (tudi mednarodne kulinarike), pridnostjo in gostoljubnostjo ponujajo turistom osebni pristop ter zaradi majhnih zmogljivosti visoko butičnost. Slovenija je izjemno bogata tudi s pitno vodo in različnimi termalnimi ter naravnimi 
mineralnimi vodami. Tisto, kar je lahko le delna prednost, saj je dolgoročno poslovno nevzdržna, pa so nizke cene v primerjavi s tujino.

Kaj je tisto, kar imamo drugačnega, na čemer lahko gradimo razlikovanje od drugih (konkurenčnih) destinacij-točke diferenciacije, tj. kaj je edinstvenega, kaj lahko izpostavimo, da se bomo učinkoviteje pozicionirali na trgu? Slovenija je ena od najbolj zelenih držav sveta, imamo izjemno velike površine gozdov (gobarstvo!), obilico lokalnih živil, razdeljenih med različne pokrajine, prvovrsten, neoporečen med, tri vinorodne dežele $\mathrm{z}$ več vinorodnimi okoliši in s svojimi avtohtonimi sortami.

Naša posebna zgodba je kranjska čebela, med, čebelarstvo, kot simbol ohranjene, neokrnjene in čiste narave, pravica do pitne vode, ki je zapisana $v$ slovenski ustavi, skrb za okolje, odnos Slovencev do narave in lastnosti kranjske čebele, ki jih lahko povezujemo s Slovenci (odpornost in delavnost).

Slovenija se bo pozicionirala kot država, ki na majhnem prostoru ponuja največ pristnih okusov narave; dežela, kjer se točita med in vino - preplet treh povsem drugačnih podnebij, država, kjer se mediteranski svet stika $\mathrm{z}$ alpskim in s panonskim, edina država, kjer na tako majhni površini najdemo tri povsem drugačne vinske dežele $s$ povsem drugačnimi vini, pri čemer so naša vina v samem svetovnem vrhu in med poznavalci med bolj iskanimi. Vsa gastronomska doživetja bomo ponudili prek zgodbe najbolj zelene destinacije na svetu in gostom predstavili, kako zelo je gastronomija stkana z neokrnjeno naravo, živili in s surovinami, pridelanimi na sonaraven način, $v$ vrtovih, gozdovih, na travnikih in pašnikih.

Glavni prednosti slovenske gastronomije sta zagotovo raznolikost gastronomske regije in bogata prehranska dediščina. Velika priložnost je možnost sonaravnega kmetovanja in pridelava hrane na ekološki in biodinamičen način - ta način pridelave hrane je pozitiven za prihodnost Slovenije v smislu varovanja okolja, zdravja ljudi ter promocije regije kot sonaravne gastronomske regije tako v evropskem kot v svetovnem merilu.

Osrednja točka akcijskega načrta je poglavje »Glavna strateška področja«, v katerem je opredeljen način uresničevanja zastavljenih marketinških ciljev. Razdeljeno je na 6 podpoglavij:

1. zakonodajni okvir,

2. znaki in ocenjevanje kakovosti v gastronomiji, 
3. spodbujanje dviga kakovosti,

4. izobraževanje,

5. trženje,

6. organizacijski okvir in mednarodno delovanje,

Vsako podpoglavje vsebuje kratko analizo stanja na referenčnem področju in rešitve za urejanje trenutnega stanja. Pri vsakem področju so navedeni tudi ukrepi za odpravo stanja (skupaj z nosilci). Podrobneje so opisani v dokumentu.

\section{Skupine gastronomskih turistov}

Kar je še posebej pomembno za razumevanje nadaljnjega trženja gastronomskega turizma, je opredelitev ključnih skupin gastronomskih turistov in njihovih značilnosti. Tudi ta del smo opredelili v »Akcijskem načrtu« in vsebino predstavljamo v nadaljevanju. Ključne ciljne skupine in trgi so opredeljeni s pomočjo pregleda literature s področja segmentacije ter raziskav sтo:

- persone ciljnih skupin slovenskega turizma (Valicon, 2016) in

- identifikacije tržnega potenciala na izbranih trgih (Valicon, 2018) ter dodatno dopolnjene in preverjene $\mathrm{z}$ deležniki.

Pri izboru destinacije ima poglavitno vlogo njen ugled. Glavni sestavni del turistične ponudbe je tudi hrana. Hrana in kultura prehranjevanja v veliki meri prispevata $\mathrm{k}$ ugledu, ki ga ima destinacija, hkrati pa sta ključni pri oblikovanju pričakovanj bodočih turistov o določeni destinaciji. V zadnjem času predstavljajo velik vzpon trženjske aktivnosti v povezavi z gastronomskim turizmom. Doživetja turistov s hrano in kulturo prehranjevanja so opredeljena kot živa doživetja destinacije, kot del dnevnih rutin turistov in kot glavni del turistične potrošnje. Raziskave poudarjajo, da je zagotavljanje pozitivnih, nepozabnih doživetij turistom bistveno za turistično gospodarstvo, saj turisti doživete izkušnje kognitivno uporabijo pri odločanju za prihodnja potovanja.

Glede na pomen, ki ga ima gastronomija pri doživljanju turistov v določeni destinaciji, sta ključna:

- odnos, ki ga imajo turisti do gastronomije: primarni ali sekundarni motiv za prihod gostov, ugotavljanje sociodemografske značilnosti posamezne turistov; 
- ekonomski vpliv posamezne skupine na potrošnjo (strošek prehrane na destinaciji).

Vliteraturi navajajo različna poimenovanja skupin gastronomskih turistov. Hall in Mitchell (2001) sta opredelila 4 nivoje interesa za hrano kot motiv za potovanje:

- močan, kjer je hrana primarni motiv,

- zmeren, kjer so hrana in dogodki povezani,

- šibek, kjer se turisti udeležujejo dogodkov, poveznih s hrano, zaradi drugačnih izkušenj,

- šibek/neobstoječ, kjer je hrana le potešitev lakote.

$\mathrm{V}$ nadaljevanju predstavljamo podobne skupine gastronomskih turistov glede na stopnjo motiva njihovega prihoda, ki je lahko primarni, sekundarni ali pa je zgolj potreba (Slovenska turistična organizacija, 2018).

Predani gastronomski turisti, ki jim je gastronomija primarni motiv prihoda na določeno destinacijo ali vsaj ena od glavnih aktivnosti v določeni destinaciji. Pričakujejo vrhunsko storitev in kulinariko, želijo poskusiti nekaj novega, trendovskega, želijo uživati v kulinaričnih in vinskih dobrotah, spoznati lokalno hrano, želijo veliko užitka in zabave ter posebnih doživetij.

To so:

- družabni foodieji in

- urbani potrošniki.

Foodie je ljubitelj hrane, ki objavlja oz. izraža svoja mnenja o hrani in restavracijah na družabnih omrežjih, kjer se povezuje z drugimi pripadniki skupin ljubiteljev hrane. Zanj je hrana življenjski slog, pomemben element družabnega sloga.

Zainteresirani gastronomski turisti so tisti, za katere so hrana, pijača in gastronomska doživetja pomembni, a ne ključni pri izboru destinacije. Na hrano gledajo kot na prostočasno aktivnost. V Slovenijo prihajajo na podlagi drugih motivov, to so: zdravje, wellness, narava ali pristna doživetja mesta in zabave v njej. Po navadi posegajo po lokalni, zdravi prehrani, v glavnem $\mathrm{v}$ tradicionalnih gostilnah, tudi v vrhunskih restavracijah s ponudbo lokalnih, svežih in zdravih živil. Nekatere, ki iščejo doživetje mesta, zanimajo lokalna scena, lokali za mlade, trendovski lokali, lokali s hitro prehrano, pivnice, bari ipd. Prav tako jih zelo zanimajo gastronomske prireditve. 
Mednje so uvrščeni tisti, ki izkazujejo interes po gastronomski ponudbi, ko so že v Sloveniji, sicer pa je bil primarni motiv prihoda drug. To so:

- sproščeni eskapisti,

- lepotni razvajenci,

- večno mladi,

- aktivni nostalgiki,

- urbani ozaveščeni in

- brezskrbni mladi.

Pri naključnih gastronomskih turistih sta hrana in pijača zgolj potreba. Gastronomske produkte izbirajo naključno in na lokaciji, kjer so zaradi svojih primarnih motivov. Pričakujejo dobro gastronomsko ponudbo za nižjo ceno. Med te smo uvrstili tiste, ki niso zainteresirani za gastronomsko ponudbo:

- zeleni raziskovalci,

- avanturisti,

- predane mame in

- aktivne družine.

V akcijskem načrtu so pri vsaki skupini navedeni glavni gastronomski izdelki, posebni poudarki, ki jih ima posamezna persona, ter nekaj značilnosti, ki so pripomogle k lažjemu vrednotenju posameznih segmentov.

\section{Glavni gastronomski turistični proizvodi}

V akcijskem načrtu so opredeljeni tudi glavni turistični proizvodi. V Sloveniji so glavni gastronomski proizvodi (Slovenska turistična organizacija, 2018): vrhunske restavracije, kakovostne restavracije, gostilne, vinske kleti, gastronomske prireditve, turistične kmetije, t.i. gastronomska doživetja, planinski domovi idr. Predstavljeni so v nadaljevanju.

\section{Vrhunske restavracije in drugi GPO}

Gre za restavracije in druge vrste gostinskih prehranskih obratov (gostilne, okrepčevalnice, bistroji ...), ki so bili uvrščeni v Gault \& Millau Slovenija $\mathrm{z}$ več kot 15 točkami. Imajo individualen pristop do gosta, priznanega šefa kuhinje in dobro usposobljeno osebje. Jedilniki so 
pripravljeni s kreativnostjo, prezentacija jedi iz svežih sestavin je domiselna. Dobra postrežba dopolnjuje visoko kakovost jedi in presega pričakovanja gostov. Somelier oz. strokovnjak za izbiro vin svetuje glede prilagajanja ponudbe. Ambient je zelo prijeten in $\mathrm{z}$ uporabo kakovostnih materialov ustvarja vtis ekskluzivnosti. Cena je visoka.

\section{Kakovostne restavracije in drugi GPO}

To so restavracije, ocenjene v vodniku Gault \& Millau Slovenija z manj kot 15 točkami. Njihova ponudba je manj kompleksa in dovršena od vrhunskih, a še vedno visokokakovostna. Ponujajo širok izbor mednarodnih in/ali domačih jedi, pogosto le/tudi določen tip jedi (npr. morska, kitajska, vegetarijanska hrana). Ambient uskladijo s ponudbo kakovostne hrane po sprejemljivi ceni.

\section{Gostilne}

So ena od sestavin dediščinske in sodobne kulinarične prepoznavnosti. Stoletja sooblikujejo podobo gastronomske kulture in pomenijo pomembna središča družabnosti, uživanja ob dobrih jedeh in odličnih vinih ter okolja za sestanke, sprejeme in praznovanja. Razvijale so se kot značilne družinske gostinske dejavnosti, kjer odkrivajo okuse hišnih, lokalnih, regionalnih in slovenskih jedi. Ponujajo predvsem širok izbor domačih jedi po sprejemljivi ceni.

\section{Vinske kleti (klasifikacija glede na uvrstitve vin na lestvice, ocene iz ocenjevanj, posebna zgodba, dodatna ponudba, navezava na naravo)}

$\mathrm{V}$ vinskih kleteh ponujajo ogled kleti in prostorov za proizvodnjo vina, degustacijo vina, kulinarične pogostitve ter nakup pridelkov in izdelkov. Sem uvrščamo tudi vinske ceste in druge gostinske objekte na vinskih cestah z vinskimi ponudniki - vinogradniki in vinarji, ki ponujajo svoja vina in nekatere jedi. Vrhunske vinske kleti so znane po vrhunskih vinih, gostitelji pa redno poskrbijo za kulinarično spremljavo.

\section{Gastronomske prireditue}

Slovenske gastronomske prireditve so raznovrstne kakor tudi destinacija sama: Brda in vino, Izola Orange Wine, Odprta kuhna, Ljubljanska vinska pot, Festival vin in kulinarike, Okusi Vipavske, Sladolent, Gourmet Cup, Salon Sauvignon, Dnevi poezije in vina, Sanje v 
Medani, Rebula Masterclass ... Najpomembnejše so tiste, ki združujejo vrhunsko kulinariko $\mathrm{z}$ vinom (okrogle mize, predavanja, dejavnosti), pri čemer so lokalni kulinarični festivali (golaža, kozjanskega jabolka, kakija, oljčnega olja, pohorske omlete ...) zaželeni, a je zanje manj mednarodnega interesa.

\section{Gastronomska ponudba na turističnih kmetijah in pri pridelovalcih živil}

To so solinarstvo, oljarstvo, čebelarstvo, sirarstvo, zeliščarstvo, sadjarstvo, vrtičkarstvo idr. Ključno je spoznavanje pridelave določenega živila. Tu leži največji potencial Slovenije kot gastronomske destinacije: ponudba, ki bi gostom širila obzorja. K tej skupini bi priključili tudi obiske tržnic, kjer veliko pridelovalcev prodaja svoje izdelke in so tudi zanimive kot turistične atrakcije.

\section{Posebna gastronomska doživetja}

Gre za doživetja, vpeta v naravo in lokalno (kulturno) okolje. Slovenija je destinacija, ki zaradi svoje raznolikosti in pristne izkušnje omogoča doživetja po meri gosta, zanje pa je na trgu mogoče doseči višjo ceno. Doživetja, povezana z naravo, so:

- različne oblike piknikov, lova, ribolova, nabiranja plodov (npr. gobe, zelišča, jagodičevje),

- kosila ali večerje v naravi (npr. med vinogradi na Krasu, v Vipavski dolini in slovenski Istri; na gozdni jasi; v nacionalnem parku; kulinarično popotovanje v Kranjski Gori, kjer vsakega od petih hodov ponudijo na drugi lokaciji; tematske kulinarične poti v okolici Rogle ...),

- doživetja na posebnih, neobičajnih lokacijah, povezanih s kulturo, $\mathrm{z}$ industrijsko dediščino ali celo s športno infrastrukturo (npr. večerja v operi, zidanicah, nekdanjem velenjskem rudniku, muzejih, najstarejšem hlevu v Sloveniji, na kabinski žičnici, muzejskem vlaku, gradovih: sevniški, Blejski, Ljubljanski grad idr., kulinarične ture po Ljubljani in Bledu ...).

\section{Planinski domovi}

Gre za obrate, ki so namenjeni krajšemu počitku in oskrbi planincev. Ambient je enostaven in čist, strežba samopostrežna. Ponujajo slovensko hrano (jota, golaž, zavitki, štruklji, žganci ...). 


\section{Drugi gostinski obrati}

Gre za ponudbo v hotelih, zdraviliščih, kampih in drugih nastanitvenih obratih. Turisti poskusijo tudi ulično prehrano, hrano na stojnicah, v bifejih ... Ponudba variira od vrhunskih restavracij do enostavnih, tudi samopostrežnih restavracij.

\section{Zaključek}

Gastronomski turizem je res zelo zanimiva in vseobsegajoča vrsta turizma, saj proizvode te vrste konzumira praktično vsak turist. Kakor tudi pri umetnosti ali športu je vsak potrošnik tudi poznavalec dejavnosti in vsak posameznik ima mnenje o hrani in pijači. V tem poglavju smo poskušali predstaviti samo nekaj osnovnih značilnosti gastronomskega turizma. Področje je po eni strani zelo znano, a v znanstvenem smislu v slovenskem prostoru še precej neraziskano, saj od raziskovalcev zahteva visoko stopnjo interdisciplinarnosti.

Gastronomski turizem je cela paleta turističnih proizvodov, storitev in doživetjih, od obiskov vrhunskih restavracij do obiska pridelovalcev hrane, vinarjev ipd. Slovenija se na svetovni zemljevid znanih gastronomskih destinacij šele postavlja. V letu 2018 smo dobili prvi mednarodni vodnik Gault Millau, leta 2020 dobimo tudi prve Michelinove zvezdice, že več let se Ana Roš s Hišo Franko uvršča med 50 najboljših restavracij sveta. $V$ akcijskem načrtu smo si postavili tri cilje: ustvarjanje višje dodane vrednosti, zagotavljanje trajnosti in predvsem povečanje mednarodne prepoznavnosti. Gastronomske turiste želimo prepričati z zgodbo trajnosti, s ponudbo lokalnih živil in lokalnih zgodb, ponudbo tistega, kar mi smo, in ne s posnemanjem trendov iz drugih destinacij. Za svoje strateške napore za dvig kakovosti gastronomije smo prejeli tudi naziv Evropske gastronomske regije 2021.

Potrebno je tudi poudariti, da gre za zelo nemnožično vrsto turizma, zelo trajnostno in predvsem za tisto vrsto, kjer imamo možnost biti to, kar smo, in s tem uspešno konkurirati na mednarodnem turističnem trgu. Slovenija ima vse potrebne sestavine, da postane nova "vroča" gastronomska destinacija, a se ne smemo bati, da bo pot do tam dolga in naporna.

\section{Literatura}

Ellis, A., Park, E., Kim, S., in Yeoman, I. (2018). What is food tourism? Tourism Management, 68, 250-263. 
Gačnik, A. (2014). Vinski in gastronomski turizem, strateška razvojna priložnost Slovenije. Vinsko kulinarični trendi, 23-25.

Galičić, V. (2014). Leksikon ugostiteljstva i turizma. Fakultet za menadžment u turizmu i ugostiteljstvu Opatija.

Hall, C. M., in Sharples, L. (2003). The consumption of experiences or the experiences of consumption? An introduction to the tourism of taste. V C. M. Hall, Food tourism around the world: Development, management and markets (str. 1-24). Butterworth-Heinemann.

Hall, C. M., in Mitchell, R. (2001). Wine and food tourism. V N. Douglas, N. Douglas in R. Derrett (ur.), Special interest tourism: Context and cases Brisbane (str. 307-329). Wiley.

Kalinšek, F. (2020). Slovenska kuharica (8. izd.). Food Cool Tour.

Lebe, S., Fuchs, W., Mundt, J. W., in Zollondz, H. D. (2012). Leksikon turizma. Multidisciplinarni raziskovalni institut Maribor.

Lebe, S. S. Blažič, P., Bogataj, J., Klančnik, R., Milfelner, B., Mlekuž, Ž., Nemanič, J., Polak, M., Prager, W., Protner, B., Protner, J., Ravnikar, B., Schiemann, K., Selinšek, J., Senekovič, B., Skvarča, M., Sršen, T., in Šenekar, T. (2006). Strategija razvoja gastronomije Slovenije [raziskovalno poročilo]. Multidisciplinarni raziskovalni institut Maribor.

Long, M. L. (2004). Culinary tourism. Univerisity Press of Kentucky.

Marković, S., Raspor, S., in Šegarić, K. (2010). Does restaurant performance meet customers' expectations? Tourism and Hospitality Management, 16(2), 181-195.

Okumus, B., Koseoglub, M. A., in Ma, F. (2018). Food and gastronomy research in tourism and hospitality. International Journal of Hospitality Management, 73, 64-74.

Pleiweis, M. (1868). Slovenska kuharica ali Navod okusno kuhati navadna in imenitna jedila.

Sajovic, K. (2019, 17. december). Večerja v Nomi, 2. restavraciji sveta-od račjih možganov do srca severnega jelena. MMC RTV sLO. https:// www.rtvslo.si/tureavanture/kulinarika/vecerja-v-nomi-2 -restavraciji-sveta-od-racjih-mozganov-do-srca-severnega-jelena/ 509230

Slovenska turistična organizacija. (2016). Tuji turisti v Sloveniji: analiza ankete o tujih turistih v Sloveniji 2015 [brošura]. https://www .slovenia.info/uploads/dokumenti/Tuji_turisti_v_Sloveniji_2015 _short_21609.pdf

Slovenska turistična organizacija. (2018). Akcijski načrt razvoja in trženja gastronomskega turizma 2019-2023 [brošura].

Uran Maravić, M. (2014). Znak kakovosti ljubljanskega turizma - LQS 2014 [interno gradivo]. Turizem Ljubljana.

Uran Maravić, M. (2017). Ocenjevanje kakovosti v gostinstvu. Založba Univerze na Primorskem. 
Valicon Tourism. (2016). Persone ciljnih skupin slovenskega turizma: poročilo [predstavitev v PowerPointu]. https://www.slovenia.info/ uploads/dokumenti/raziskave/sto157_persone_ciljnih_skupin_slo _turizma.pdf

Valicon Tourism. (2018). Identifikacija tržnega potenciala: primerjalno poročilo raziskave med anketiranimi državami: Avstrija, Francija, Nemčija, Italija, Nizozemska, Poljska, Združeno kraljestvo, Rusija, Belgija, Češka, Danska, Madžarska, Španija, Češka, Švica [predstavitev v PowerPointu]. https://www.slovenia.info/uploads/poslovno/ raziskave_analize/sto162_primerjalno_porocilo.pdf

Vinerean, A. (2012). Promises of gastronomic tourism. Revista Economica, 65(4), 21-32.

Vodnik, V. (1799). Kuharske bukve. Gassler.

World Tourism Organization. (2012). Global report on food tourism.

World Tourism Organization. (2019). Guidelines for the development of gastronomy tourism.

Woolf, S. J. (2018). Amber revolution: How the world learned to love orange wine. Interlink. 